\title{
Guide-interpreter's language identity as an excursion discourse factor
}

\author{
Anna A. Gureeva - Elina Yu. Novikova - Vera A. Mityagina
}

\section{DOI: $10.18355 /$ XL.2016.09.02.90-102}

\begin{abstract}
The paper deals with an excursion as a genre of oral communication which has its strict structure. The strategies of an excursion text are revealed and discovered. The authors consider the peculiarities of the guide-interpreter's language identity as a discourse factor of an excursion and analyze the specific features of the guideinterpreter's communicative actions in different parts of an excursion. The authors determine the influence of the guide-interpreter's professional and discourse pragmatically adequate strategies on the realization of an excursion communicative actions program and reveal the factors that have an impact on the guide-interpreter's choice of linguistic means during an excursion.

Key words: guide, guide-interpreter, interpreter's language identity, tourist discourse, tour guidance, excursion
\end{abstract}

\section{Introduction}

Tourism development as one of the top priorities is the subject of numerous all-Russian and regional programs and researches in recent times. An attractive cultural space forming and a tourist attractive image making in modern cities play the key role in region's economic attractiveness rising. Modern tourism services develop under the conditions of intercultural and cross-cultural globalization and include accessibility in the language and communicative aspect (Novikova, 2014: 240). The international cultural tourism is a way to learn the so-called strange foreign culturebound items as well as to improve culture knowledge on the whole. As P. Pearce marked, the essence of tourism consists of the desire for seeing something new, unknown (Pearce, 1991: 8).

\section{Excursion as a way of intercultural communication}

Research of different tourism aspects is presented by numerous papers by modern authors. G. Dann's papers are devoted to the tourism language analysis (1996). M. Rázusová pays particular attention in her papers to the language as a part of tourist discourse. The significance of semiotics for tourist discourse is explained in the papers by J. Culler (1981), M. Danesi (1998), C. Echtner (1999), J. Frow (1991), M. Mehmetoglu \& G. Dann (2003). The peculiarities of cultural tourism are shown by the papers of E. Bruner (2005), J. Henderson (2001), H. Hughes, \& D. Allen (2005), B. Kirshenblatt-Gimblett (1998), A. Pritchard \& N. Morgan (2001). Culture, history, traditions, natural resources, landscape, all is under the researchers' focused attention.

A favorable image of the so-called strange, foreign country and propriety of the undertaken marketing strategies to make regions attractive for tourists depend on successful communication within intercultural tourist discourse. Tourist discourse is multifunctional and suspects many-sided research paradigms considering diverse genre peculiarity and the role which tourism plays in the modern society. In the context of achieving successful international cultural tourism communication, we consider it to be interesting, logical and actual to appeal to the research of one of the most needed type of tourist activity - excursion activity and, as Alefirenko mentions, "the integration of the discursive and linguocultural consciousness is so organic that it is extremely difficult to give an adequate interpretation of discourse without it" 
(Alefirenko, 2014: 36), we will try to find out social and communicative and linguopragmatic peculiarities of the excursion tourist discourse. The analysis is based on several sightseeing tours of Russian cities, represented on the Internet.

An excursion is a group or individual sightseeing usually within city tourism aimed at getting new culture and values knowledge and aesthetic enjoyment. As T.V. Demidova marks, an excursion is "a process of sensory and logical perception of the world" (Demidova, 2008). Excursion types differ in form, content, purpose, membership, presentation devices of excursion services, etc. New forms and conditions of excursion appear under the conditions of the modern changing terms of the international tourism, increasing a role and an accessibility of information technologies, changing of tourists' demands. We try to represent schematically formal, specific peculiarities of excursion types in Table 1.

Table 1

\begin{tabular}{|c|c|c|}
\hline Discourse type & \multicolumn{2}{|l|}{ Tourist } \\
\hline Discourse variety & \multicolumn{2}{|l|}{ Excursion } \\
\hline $\begin{array}{l}\text { Excursion type } \\
\text { according to the place }\end{array}$ & city sightseeing & special-purposed \\
\hline $\begin{array}{c}\text { Excursion type } \\
\text { according to the theme }\end{array}$ & \multicolumn{2}{|l|}{$\begin{array}{l}\text { historical, } \\
\text { natural history, } \\
\text { art history, } \\
\text { industrial, } \\
\text { literary, } \\
\text { mystical, } \\
\text { interior, } \\
\text { wine-producing, } \\
\text { night, } \\
\text { cookery, } \\
\text { castles, } \\
\text { etc. }\end{array}$} \\
\hline $\begin{array}{l}\text { Excursion type } \\
\text { according to the } \\
\text { stylized design }\end{array}$ & \multicolumn{2}{|l|}{$\begin{array}{l}\text { fancy-dressed, } \\
\text { tactile, } \\
\text { olfactive, } \\
\text { etc. }\end{array}$} \\
\hline $\begin{array}{l}\text { Excursion type } \\
\text { according to the used } \\
\text { technologies }\end{array}$ & \multicolumn{2}{|c|}{$\begin{array}{c}\text { without using backup, } \\
\text { with using of audio-guide, } \\
\text { with using of audiovisual tools (a tablet PC, MP3, smartphone) }\end{array}$} \\
\hline $\begin{array}{l}\text { Excursion type } \\
\text { according to the travel } \\
\text { mode }\end{array}$ & \multicolumn{2}{|l|}{$\begin{array}{l}\text { pedestrian, } \\
\text { bus, } \\
\text { wheelchair, } \\
\text { segway, } \\
\text { bicycle, } \\
\text { etc. }\end{array}$} \\
\hline $\begin{array}{l}\text { Excursion type } \\
\text { according to the } \\
\text { interaction mode }\end{array}$ & \multicolumn{2}{|c|}{$\begin{array}{l}\text { direct communication in mother/foreign language, } \\
\text { indirect communication in mother/foreign language }\end{array}$} \\
\hline $\begin{array}{l}\text { Excursion type } \\
\text { according to the } \\
\text { membership }\end{array}$ & \multicolumn{2}{|c|}{$\begin{array}{c}\text { Gide - excursionists, } \\
\text { guide-interpreter - excursionists, } \\
\text { audio guide - excursionists, } \\
\text { audio guide - indirect excursionist, } \\
\text { indirect guide - indirect excursionists }\end{array}$} \\
\hline
\end{tabular}

XLinguae Journal, Volume 9 Issue 2, April 2016, ISSN 1337-8384 


\section{A guide-interpreter as a key participant}

The main participant of an excursion is a guide. As U.A. Zharkova marks, "a guide in the situation of the communication is one of the perfect examples of a rhetor, whose goal is to pay audience's attention to the very part of reference visual field, that the excursion is devoted to" (Zharkova, 2012: 122). The situation of the intercultural excursion communication supposes a guide-interpreter as the main participant. His/her communication programme reveals a range of peculiarities and differences from a guide's activity within one linguoculture.

Thus, according to the officially assigned regulations on guide-interpreter activity in Federal Tourism Activity Control Act in the Russian Federation, a guideinterpreter is a professionally trained person, who speaks a foreign language fluently. This language knowledge is necessary for interpreting and excursionist's (tourist's) acquaintance with the sights in the country (place) of temporary stay (see: http://ozpp.ru/zknd/turi/turi 3777.html).

C. Angelelli points out, that today the focus is not only on interpreters, but also on the construction of his/her identity (Angelelli, 2012). We think that a guideinterpreter is a professional language identity with certain discourse dependent programme of actions, strategies and competence for the intercultural communication realization in the course of acquaintance with culture and values bound items of a foreign country. This type of language identity reveals synergy of a guide's language identity (LI) and an interpreter's LI, as it combines the discourse characteristics of professional guide on the one hand, and the professional competence of an intercultural mediator, who is able to realize the communication in a foreign language, and an interpretation activity, on the other hand.

The guide's LI exists only within the framework of the excursion tourist discourse and according to T.V. Demidova forms due to: depends on;

1) account of recipient's factor, whose perception the excursion text

2) excursion communication control;

3) influence on the recipients;

4) use of linguistic means during excursion text development, including general standards observance and individualization display (Demidova, 2009).

On the contrary, the interpreter's LI is multifunctional and many-sided. A lot of papers in Russian linguistics are dedicated to the language identity research A.B. Bushev (2010a, 2010b), O.N. Shevchenko (2005), L.A. Nefedova (2011), S.N. Plotnikova (2008), A.A. Gureeva (2014), etc. The analysis of these papers makes it possible to define the interpreter's LI as a cultures mediator, combining a communicative, discoursive and translatological metalinguistic identity. As a result of interpretation and reexpression of communicants' statements senses, an interpreter transforms the communicative situation, transposes it into a successful interlanguage and intercultural interaction. The process of interpreting means an interaction with bearers of different cultures and languages. The interpreter being an active participant in intercultural communication plays a central role in its formation (Mason, 2004: 89) and "certainly influences on the creation and result of the main social processes" (Poddubnova, 2013: 85). A dialogue between languages and cultures occurs at both receptive and productive levels. In the context of the multicultural environment, the interpreter's skills to notice and understand a foreign culture through the lens of the own cultural identity as well as translate these skills to the members of other linguoculture through the interpreter's activity assume ever greater importance.

The social and cultural pragmatics of the guide-interpreter's LI depends on many factors of institutional character of tourism discourse. Within the interpreter's 
communicative behavior all components of his/her language identity structure reveal including goals, purposes as the motivational layer constituent parts; skills of verbal means usage in compliance with the language standards and communicative situation; knowledge, ideas, concepts as a result of formed linguistic word-image that represents a linguo-cognitive layer of the identity structure. The activity causes of a guideinterpreter as translator in general are purposed to the translation of linguocultural bound terms, value systems and mentality of one or another culture. Different times and cultures may well conceptualize the notion of "translation" in very different ways (Chesterman, 2006: 4). According to A.A. Gureeva, the guide-interpreter's cognitive base makes it possible to orientate easily within the cultures in contact (Gureeva, 2014).

The excursion methods for foreigners differ considerably from the work with tourists of your own linguoculture. For foreigners is necessary to consider more carefully the excursion objects choice oriented to the limited, often stereotyped notion and knowledge. "From the perspective of cultural linguistics, the explanation of ethno-cultural identity must be sought in the words that capture images of scrutable objects and phenomena" (Alefirenko, 2015: 2). It is important not only to show cultural and historical peculiarities to foreigners, but also to form an attractive image of "strange" county, attract interest to its culture. In addition, the perfect language skills and translation techniques are an essential factor of a successful excursion. The ritualized communication character subordinated to the conventional program of the communicative situation stipulates the translation and other skills realization and prescribes the choice of the communicative strategies and devices. The analysis of papers by E.V. Dashkova (2012), A.D. Bogdanova (2010), E.U. Novikova (2014), T.Y. Burachenko (2009), M.V. Cherezova (2009) and others, dedicated to a guideinterpreter's competence content, enables to single out the following competence groups:

$\begin{array}{cl}\text { Group 1 } & \begin{array}{l}\text { general scientific, } \\ \text { fundamental } \\ \text { competences }\end{array} \\ \text { Group 2 } & \begin{array}{l}\text { social and personal } \\ \text { competences } \\ \text { professional } \\ \text { competences: }\end{array}\end{array}$

\section{Group 4 interpreter competences}

The guide-interpreter's language identity and communication conditions, stipulated by the situation, have an influence on the excursion text production and implement the discourse significant features. As J. Lihua, H. Chong, J. Jinlin and F. Yue write in their paper, interpreter-mediated communication involves social interaction among all participants and the interpreter's presence and actions has led to new views on the interpreter's role as a "cultural broker" or "coordinator" in the communication process (Lihua, Chong, Jinlin and Yue, 2014). A real excursion can go under the favorable/ unfavorable/ unpredictable conditions, specified by such risk factors as weather, transport, hardware, psychological and physical condition, "microclimate"/ excursion group mood, etc. Thereupon we agree with T.V. 
Demidova's attitude that the excursion text is produced with the usage of different language means within the favorable situation context, whereas the excursion is verbalized through the shortened scenario within force-majeure circumstances (Demidova, 2008: 16). A target group of excursionists is an important pragmatic factor of excursion. Age, social and cultural peculiarities, membership of certain professional group, purpose and duration of the trip influence the quality of an excursion text. The guide-interpreter should take into consideration the communicative and pragmatic peculiarities of the situation in whole and the excursion group in particular (tourists can be representatives of the different social strata and occupations: students, pensioners, businessmen, representatives of middle class, millionaires, famous actors, politicians) (Novikova, 2014).

\section{A guide-interpreter's communicative action}

An excursion text in the main part contains information about historical, architectural, local historical, sociocultural peculiarities of an excursion object. The guide resorts some professional and discourse significant and pragmatic adequate strategies of the excursion conduct with the realization of communicative actions program. The guide also makes a choice of linguistic means in the framework of his/her communicative action types and the undertaken strategies. The whole set of communicative actions - communicative behavior of individuals - makes the functional characteristic of the culture. The identification of the communicative action type is an important methodological tool. It seems logical to examine the communicative action as a procedural discourse unit (Mityagina, 2007: 106-107), which is concluded by us on the basis of the typology of social action by Max Weber (Weber, 1990: 607) and the ideas of the universal pragmatics by Jurgen Habermas (Habermas, 1984; Habermas, 1985). The used typology of the social actions is based on the intentional description and contains 4 types:

1. Purposeful rational communicative action is based on an accurate goal awareness and notable for aimed relatedness with the linguistic means, adequate for the achievement of this objective goal.

2. Value oriented communicative action is based on the belief in the absolute value of this action, which is self-sufficient and independent of its possible results. In contrast to the value rational action, the sense of the value oriented action does not consist in the achievement of an external goal, but in subordination to the certain "rules" and "requirements". An individual sees his duty in compliance of these "rules" and "requirements". Marking this action as the value oriented not the value rational as in M. Weber's papers emphasizes that the compliance with the value purpose in many cases goes beyond the rational, implements sociocultural stipulated model of the communicative behavior.

3. Traditional communicative action is a mentality conditioned procedural step of the usual daily people behavior, in which the compliance with traditions, customs plays a key role.

4. Affective communicative action depends on the emotional condition of acting subject and performs as this condition demonstration (Mityagina, 2008: 166).

What communicative actions are performed by a guide-interpreter? How are they connected with communicative strategies?

The excursion texts analysis made it possible to define that three types of the communicative action are characteristic for this subspecies of the tourist discourse: purpose-rational, value-rational and traditional. The affective communicative action is related to the interpreter's spontaneous negative emotions that contradict the excursion genre-formative principle. This actions type can take 
place in the definite conflict situation, external irritants, etc, but it was not noticed by us within the analyzed material.

An excursion as a genre of verbal communication has its strict structure: an introduction, a main body, and a conclusion. These three types of communicative actions implement in different ways in different parts of excursion. A purpose-rational action prevails in each of the parts. The character of a so-called dialogued monologue of an excursion text makes it possible within the framework of the value-rational action with the use of language means to verbalize the following strategies in an excursion text:

- $\quad$ strategy of group interaction organization (information-didactic)

- $\quad$ strategy of knowledge transmission

- $\quad$ strategy of emotion transmission (emotive)

- $\quad$ strategy of compliment.

Thus, the peculiar features of the introduction part of a "live" interactive excursion include introduction of the participants, information about the excursion object/ route and purpose, clarification of organizational issues. The guide-interpreter addresses to the guests, chooses linguistic means which realize phatic function, strategies of highlighting, informing and instruction:

- Also wir begrüßen alle Gäste zur Rundfahrt.

- $\quad$ Es gibt auch Möglichkeit, einige Orte in der Umgebung Wolgograds zu besuchen. Überlegen Sie bitte darüber und sagen Sie es uns im Voraus. Wenn Sie es möchten, dann müssen wir es noch zusätzlich organisieren.

- We are glad to welcome you in the Hero City of Volgograd!

- $\quad$ During our tour you will learn about the history of the southern districts of Volgograd and history of the Volga-Don Shipping Canal, visit mosque in Malye Chapurniki village, the most ancient one in the region.

- During our tour to the Volga Delta and Lotus Field a hunts-man-guide will go with you on boats for 2-4 people in virgin nature reserves, narrow channels and with pure clear water.

- $\quad$ Today we will go to Rossoshky.

The main body is the most informative part of an excursion text. According to V.A. Mityagina, value-rationality is connected with performing the task of presenting the object in such a way, that an appeal to the text-recipient in the directed positive presentation of the excursion object becomes adequate to its analytical and hermeneutical ability (Mityagina, 2009: 89). Here, the strategy to transmit the knowledge about the excursion object and a wish to present a region/ place/ object as a unique, historically important and attractive one:

- Wir sind in einer Kosakenregion. Die Kosaken sind eine ethnische Schicht, die eine sehr wichtige Rolle in der Geschichte der Region gespielt haben.

- Now we are at the Astrakhan Kremlin, the pearl of the Lower Volga region, the outstanding monument of the military and engineering art and architecture of the letter half of the $17^{\text {th }} \mathrm{c}$.

- During the journey you will see birds living in the Delta in their natural environment. You can also see some animals of the Delta such as a raccoon, a mink and a wild boar. Luxurious lotus fields amaze with their beauty. You have never seen before such a wonderful picture.

At that, during the material presentation it is important to find the so-called happy medium in order the high use of the cultural notes, precedent-related information reflecting the intercultural connections could be clear for a foreigner:

- Warum hieß eigentlich die Kathedrale Alexander Newski-Kathedrale? Alexander Newski war Kurfürst, der einen großen Sieg über die Schweden, dann 
später über die deutschen Kreuzritter gewonnen hat. Er hat in dieser Region eine große Rolle gespielt. Diese Region stand im Besitz der tatarischen und mongolischen Goldenen Horde. Alexander Newski kam hierher mit der Bitte die Stad nicht zu zerstören. Deswegen gilt er für uns Wolgograder als Schutzpatron.

- Pavlov' House is a house of soldiers and labours' heroism. During the Battle of Stalingrad a 4-storey residential building became the bastion, which blocked German forces' way to the Volga. The house is named after Sergeant Yakov Pavlov who, in September, 1942, occupied the building with his comrades-in-arms and during 58 days and nights 24 the soldiers restrained the enemy severe attacks and won the battle.

- Taranov's Spring is a group of springs giving the head of the Tsaritsa River. This miracle spring was named after an old man Taran who lived near the spring from 1858 to 1960 and died at the age of 102. During his life he looked after the spring and took care of it to prevent clay and sand filling it up. Taran' work was continued by his grandson, Nikolay Taranov, the head of Institute for Art Education, Doctor of Science and Professor of the Volgograd State Pedagogical University. Being an artist he made a stone-fence around the spring in Old Russian style and made a sculpture of Taran who looked like an old man from fairy tales.

In some cases, the guide-interpreter needs to take a negotiating positioning (Mason and Ren, 2012). The text appeal function in the framework of a question-answer dialogue is achieved through an active interaction between the guide and recipients:

- Dialogue:

- Reiseführer: Liebe Gäste, könnten Sie mir bitte helfen, wie kann man den Namen der Kirche raten?

- Gast: Nach der zweiten Ikone rechts von Christus, soviel ich weiß.

- Reiseführer: Sie haben Recht. Wirklich, die Ikonostase folgt in allen orthodoxen Kirchen dem gleichen Grundstil: In der Mitte befindet sich die "königliche Tür", rechts von der mittleren Tür die Ikone des Herrn, Jesus Christus. Daneben befindet sich die Ikone des betreffenden Kirchenpatrons oder des Kirchenfestes, dem die Kirche geweiht ist.

- Dialogue:

- Guide-interpreter: This is Stalingrad, you see?

- Tourist: Where were we this morning?

- Guide-interpreter: I'll show you. This is the Memorial Square, yes? This is the Obelisk. Do you see it?

- Tourist: We were here?

- Guide-interpreter: Yes, we were at the Obelisk. There are the graves here. And this is, this is the pre-war Central Department Store. Then we went along Mira Street. Now the plan of the city is quite different, because there is the Obelisk and Mira Street goes like this.

- Tourist: Right.

- Guide-interpreter: This is Mira Street and this is the Central Department Store where Paulus has been taken prisoner. And we were in the morning here. Just believe me it was here. It was here, it was really here.

The use of the appellative language means is dictated by the strategy of emotions and compliment transmission: 
- Dieser Platz war nach der Oktoberrevolution in den Platz der gefallenen Kämpfer umbenannt. Ich weiß nicht wie beschlagen Sie mit der russischen Geschichte sind? Ja, Sie wissen schon was Bescheid, ja?

- The Volzhsky hydroelectric power station, as you might know, is one of the biggest hydroelectric power stations in the world and the largest one in Europe. Just imagine! Today the station gives about 11 billion kilowatthours annually!

- The most important things are in the museum and we will go this way. It's impossible to see everything and we will try to see the most important things that are to my mind the most important.

-I'd like you to have an impression how the soldiers had a rest here at the front, because we will go to the dark out and you'll see from yourself how they had a rest during the battle.

- There are 4000 exhibits in the museum. Of course, it's impossible to see all of them but I'll try to show you the exhibits I like best, I like best. I always do it in such a way.

- First of all we'll go to Panorama. It's upstairs, it's very, very high, but I think we'll manage! All right! Now, let's go to Panorama!

-Do you recognize him? It's Stalin. Yes. Generalissimos we called him during the war.

The translation interpretation as a specific communication type, the content of which is an individual text interpretation by an interpreter, makes it possible to maintain that a guide-interpreter's personal experience - his/her feelings, views, motivation, associations - is not only an acceptable, but necessary part of the effective translation:

-Der berühmte Befehl 272 „kein Schritt zurück“ soll den Rückzug der sowjetischen Truppen vermeiden, ein schrecklicher Befehl, meine ich.....

- And this is Tsaritsa. They decided to bury it under the ground not to see that dirty river. But they had another way to do it. They could clean it, help the river. Yes? But they did not do that.

- I'd like to show you the poster that I love most of all. I like it very much.

Besides, a "live" excursion is characterized by the use of paraverbal means such as intonation, pace and timbre potential:

- Ah, Ja, es der Weg ist wieder gesperrt.

- And now we all can see a place which everybody knows.

There is no doubt that the main part of an excursion is a demonstration of sights, however the impression, esthetic pleasure, good-spent time are also very important for tourists. As G. Dann mentions, tourism is a sort of a game (Dann, 1996: 17-23) which is accompanied, as we think, by an expectation of entertainment and new interesting experience. Today an excursion is mainly a performance (Urry 1990, qtd. in Dann 1996: 18), a sort of show, that make it possible for a tourist to get new experience, enrich his/her knowledge and get new impressions (Razusova).

The guide-interpreter's value-oriented communicative action is subordinated to the acknowledgement of tourism values that realizes by the following strategies:

- $\quad$ entertainment strategy

- localization strategy

- $\quad$ advertising strategy

- $\quad$ stereotypes exploding strategy

- $\quad$ self-kidding strategy 
The localization strategy provides a tourist's full immersion in the atmosphere of the place, necessity to feel him/herself as a participant of a certain event. "Kindred relationship, social roles and norms are not perceived in feelings; they are a part of social and normative complex and present themselves to be norms of behaviour. Customs and traditions, religious belief, cognitive and symbolic systems, knowledge and cognition are a part of the highest level of spiritual culture" (Cukan, 2014: 22). The guide-interpreter uses different methods such as a comparison with traditions/ customs/ architectural peculiarities, etc. in order to make a foreign tourist permanently memorize and keep in mind the experienced impressions:

- Sie haben selbst die klimatischen Besonderheiten in unserer Region gespürt. Ich muss sagen, es ist noch nicht heiß bei uns. Ab morgen wird die Temperatur noch steigen. Im Sommer scheint bei uns die Sonne sehr oft, genauso wie in den besten Kurorten der Welt.

- In the Volgograd Restaurant you can try traditional Russian cuisine pelmeni, blini and kvas, food and drinks which are well-known all over the world like Italian pasta, pizza and cappuccino.

Within the advertising strategy realization, the non-verbal means are also active, such as the use of printed materials (guide-books, encyclopedias, albums, books, letters, etc.), photos, paintings/reproductions, authentic objects and so on:

- Dialogue:

- Tourist: Where are we now?

- Guide-interpreter: Where are we now? Just a moment, just a moment! We are somewhere here (showing the map to the tourists). This is Mamev Hill, this is Tsaritsa and we are here.

- Hier sind interessante Fotos aus der Vorkriegszeit. Das sind z.B. die Bilder vom Zentralen Warenhaus in der Vorkriegszeit und gleich nach der Schlacht.

- Und das ist das Bild vom Bahnhof, wo wir gerade heute Morgen waren.

A foreign tourist familiarizes with a new culture in the light of the formed stereotypes and prejudices respected to the culture, also verifies new knowledge through a projection on the existing cognitive base. The tasks of the guide-interpreter as a specialist in intercultural communication include the stereotypes exploding, exclusion of formation of a "wrong" image of a foreign country, familiarization with culture-significant values. The stereotypes exploding strategy is realized explicitly, in the situation when a guide obviously appeals to the stereotypes, and implicitly, when a tourist changes his notions during of the communication:

- Zu uns kommen sehr viele deutsche Touristen und Zeugen der Schlacht bei Stalingrad, wir pflegen wirklich gute Beziehungen, sie erzählen ihre Geschichten und Visionen des Krieges...

The stereotypes exploding strategy has the common features with the selfkidding strategy. The aim of this strategy is an intentional autoreflexive appeal to analysis/ critics/ overview of the culture-specified peculiarities of a "strange" culture:

- Für unsere ältere Generation, für Kriegsveteranen, bleibt Stalingrad immer Stalingrad. Aber, was selbst die Einheimischen sagen, nur das Zentrum der Stadt sei ein richtiges Stalingrad. Alle Gebäude hier sehen genauso aus, wie vor dem Krieg.

- Some people say that a native of Moscow is haughty and high hat. We think that Moscow is the best city in the world. It's not the most beautiful, but the most comfortable one. If one day we were in Rome or London we would say: "Well, a pretty city!" 
The exploding strategy is also a part of a communicative program of the value-oriented action as entertaining methods such as game, funny stories telling, jokes, songs performance, etc. promotes the formation of a tourism value picture in whole and in the concrete region particularly:

- My wife and I took a terrific tour with Gavin December 29. We visited Westminster Abbey, St. Paul's Cathedral, and a walking tour of London from St. Paul's back to our hotel in Southwark. Gavin is well versed in the highlights of each site - historical and architectural.He also added some humorous anecdotal comments.All in all, a very enjoyable tour.Highly recommended. (SocratesCanada Canada)

(http://www.tripadvisor.co.uk/Attraction Review-g186338-d1818020-ReviewsGavin_Webb_Tour_Guide_of_London-London_England.html)

- “Чтобы узнать город лучше."

Очень интересная экскурсия по Москве, которую я не знала. Гид Лена была очень мила, много ульбалась и рассказывала интересные и смешные истории, которые сразу впечатываются в память. Провела нас от Церкви на куличках)) до Кремля, показала старые ворота города, Романовское имение и дала совет, где покушать недорого потом. Все понравилось, всем советую!

(http://www.tripadvisor.ru/Attraction_Review-g298484-d2196855Reviews-Moscow_Free_Tour-Moscow_Central_Russia.html)

A guide-interpreter's traditional action in the communicative program is presented through the self-presentation strategy, which aimed to the forming an image of guide as a professional. As a rule, this type of the communicative action finds only an episodic verbal expression in the guide's speech, while its most complete verification can be observed in the texts of excursionists responses:

- “Exceeded all expectations. An absolute must."

I have had the pleasure and on some occasions the displeasure of numerous tours throughout the world and our tour with Gavin surpassed them all and was sublime in every way. Literally every corner that we turned with Gavin, we were met by a unique discovery that uncovered the most fascinating stories, factoids and delights. We had a 3 hour walking tour of The City of London and although I worked here, albeit it 20 years ago, I was amazd about how little I really knew and how much detail and ground Gavin managed to cover. I very rarely write reviews but I cannot over stress how special, passionate and talented Gavin is. An afternoon that I will cherish and remember forever. I can't wait until we arrange out next tour with Gavin. Sincere thanks and warmest wishes to you Gavin.

(http://www.tripadvisor.co.uk/Attraction_Review-g186338d1818020-Reviews-Gavin_Webb_Tour_Guide_of_London-

London_England.html)

- "Best walking tour yet!"

We hired Gavin for a private tour of the Old City of London. He exceeded our expectations. He gave us an amazing tour of alleyways, hidden churches; beautiful gems and a history lesson that we all agreed that if teachers taught history this way - we would all enjoy and remember it from our school days. Our daughter was with us (doing a semester abroad in London) and she told him that she was taking a class on several English 
authors; he worked in several literary references on the fly. I would definitely recommend his tour to anyone who asks

\section{Conclusion}

The research material and the authors' experience of working as guideinterpreters show that the realization form of one or another strategy always depends on the guide's language identity - the paradigm of his/her professional and personal characteristics, linguistic world-image and sociocultural attitude. The realization of the communicative action in the communicative space of the excursion has an influence on the forming of the guide's certain communicative image. Thus, an interesting typology of a guide's language identity is presented in the papers by U.A. Zharkova (Zharkova, 2012), where it is said that a guide in his activity follows some communicative models and acts as a guide-narrator, guide-erudite person, guideteacher, guide-conductor, guide-organizer, guide-host, guide-patriot, guide-joker. At the same time these and others roles can mark the communicative behavior of a guide within one excursion, as well as can be selectively presented in different situationconditioned excursions.

The article is prepared with the financial support of the Russian Foundation for Humanities, regional contest "Volzhsky Lands in the Culture History of Russia", project No. 15-14-34001 Linguistic and Translatology Logistics of Multilingual Webportal: Regional Guide within Globalization (Volgograd and Volgograd Region).

\section{Bibliograpic references}

BOGDANOVA, A.D. 2010. Professionalnaya perepodgotovka ehkskursovodov dlya raboty s inostrannymi turistami: avtoreferat diss... kandidata filol. nauk. Moscow, $169 \mathrm{p}$.

BURACHENKO, T. Kvalifikatsionnye i pedagogicheskie aspekty professii gidperevodchik. In Aktualnye problemy gumanitarnykh i estestvennykh nauk, 2009. vol. 2, n. 7, pp. 109-112.

BUSHEV, A.B. 2010a. Russkaya yazykovaya lichnost professionalnogo perevodchika: avtoreferat diss....doktora filol. nauk. Moscow, $21 \mathrm{p}$.

BUSHEV, A.B. 2010b. Russkaya yazykovaya lichnost professionalnogo perevodchika. Tver: OOO «Laboratoriya delovoj grafiki», $265 \mathrm{p}$.

CHEREZOVA, M.V. 2009. Psikhologo-pedagogicheskij analiz professionalnoj deyatelnosti gida-perevodchika. In Kultura narodov Prichernomorya : nauch. zhurn. Simferopol: Mezhvuztsentr „Krym”, n. 155, pp. 142-145.

CULLER, J. 1981. The semiotics of tourism. American Journal of Semiotics, 1, pp. 127-140.

DANESI, M. 1998. Sign, thought, and culture - A basic course in semiotics. Toronto: Canadian Scholar's Press, 393 p.

DANN, G. 1996. The language of tourism: a sociolinguistic perspective. UK: CAB International, 298 p. ISBN 0-85198-999-3

DASHKOVA, E.V. 2012. Professiya «ehkskursovod»: opyt kompetentnostnogo analiza. In Sotsiosfera, n. 3. pp. 88-96.

ZHARKOVA, U.A. 2012. Professionalnaya yazykovaya lichnost ehkskursovoda: diskursivnyj aspekt. In Lingvisticheskie aspekty issledovaniya identichnostilichnosti v izmenyayushhemsya mire: kollektivnaya monografiya/ pod red. E.N. Aznacheevoj. Chelyabinsk: Ehntsiklopediya, 232 p.

DEMIDOVA, T.V. 2008. Yazykovaya lichnost v ehkskursionno-diskursivnoj deyatelnosti. In Vestnik Chelyabinskogo gosudarstvennogo universiteta, n. 26, pp. 26- 
30. Available online: http://cyberleninka.ru/article/n/yazykovaya-lichnost-vekskursionno-diskursivnoy-deyatelnosti.

DEMIDOVA, T.V. 2009. Fenomen interdiskursivnosti ehkskursionnykh tekstov (opyt lingvokognitivnogo analiza tekstov ehkskursij po Nizhnemu Novgorodu i Nizhegorodskoj oblasti): avtoreferat diss.... kandidata filol. nauk. Tambov, 24 p. Available online: http://cheloveknauka.com/v/45819/a?\#?page $=1$.

FEDERAL LAW “Ob osnovakh turistskoy deyatelnosti v RF”. Retrieved from: http://ozpp.ru/zknd/turi/turi_3777.html.

FEDERAL Tourism activity control act in the Russian federation (as amended by Federal Laws dated January 10, 2003 No 15-Ф3; dated August 22, 2004 No 122-Ф3; dated February 5, 2007 No 12-Ф3; dated December 30, 2008 No 309-Ф3; dated June 28, 2009 No 123-Ф3; dated December 27, 2009 No 365-Ф3) http://ozpp.ru/zknd/turi/. FROW, J. 1991. Tourism and the semiotics of nostalgia. In October 57, pp. 123-151.

GUREEVA, A.A. 2014. Sotsiokommunikativnye kharakteristiki yazykovoj lichnosti perevodchika (na materiale russkogo i anglijskogo yazykov): avtoreferat diss.... kandidata filol. nauk. Volgograd, $18 \mathrm{~s}$.

HABERMAS, J. 1984. Was heißt Universalpragmatik? In Vorstudien und Ergänzungen zur Theorie des kommunikativen Handelns. Frankfurt/MaIn Suhrkamp, S. 353-440.

HABERMAS, J. 1985. Theorie des kommunikativen Handelns. Bde. 1, 2. Frankfurt/MaIn Suhrkamp. ISBN 3-518-28775-3

MEHMETOGLU, M. - DANN, G. 2003. Atlas/ti and content/semiotic analysis in tourism research. In Tourism Analysis, n. 8 (1), pp. 1-13.

MITYAGINA, V.A. 2007. Sotsiokulturnye kharakteristiki kommunikativnogo dejstviya: monografiya. Volgograd: VolGU, pp. 274-277.

MITYAGINA, V.A. 2008. Tip kommunikativnogo dejstviya v diskurse: verifikatsiya v ramkakh zhanra. In Vestnik VolGU. Seriya 2. Yazykoznanie, n.1 (7), Volgograd: VolGU, pp. 116-119.

MITYAGINA, V.A. 2009. Kommunikativnye dejstviya v turisticheskom diskurse. In Inostrannye yazyki v vysshej shkole. Nauchnyj zhurnal. Ryazanskij gosuniversitet im. S.A. Esenina, issue 4 (11), pp. 88-97.

NEFEDOVA, L.A. 2011. Yazykovaya lichnost perevodchika: kollektivnaya monografiya / otv. red. L.A. Nefedova; nauch. red. M.V. Zagidullina. - Chelyabinsk: Izd-vo Chelyab. gos. un-ta, $420 \mathrm{P}$.

NOVIKOVA, E.Yu. 2014. Ekskursionnoe obsluzhivanie kak obekt professionalnoj perevodcheskoj deyatelnosti $\mathrm{v}$ ramkakh turisticheskogo diskura In Izvestiya Saratovskogo universiteta, pp. 39-43. Available online: http://elibrary.ru/download/87399728.pdf.

PEARCE, P. 1991. Analysing tourist attractions. In Journal of Tourism Studies, vol. 2 n. 1 , pp. 46-55.

PLOTNIKOVA, S.N. 2008. Govoryashhij / pishushhij kak yazykovaya, kommunikativnaya i diskursivnaya lichnost. In Vestnik NGGU, n. 4, pp. 37-42.

RÁZUSOVÁ, M. The language of tourism, pp. 198-201. Available online: http://www.pulib.sk/elpub2/FF/Ferencik2/pdf_doc/27.pdf.

SHEVCHENKO, O.N. 2005. Yazykovaya lichnost perevodchika (na materiale diskursa B.V. Zakhodera): avtoreferat diss.... kandidata filol. nauk. Volgograd, $22 \mathrm{s.}$

WEBER, M. 1990. Osnovnye sotsiologicheskie ponyatiya. In Izbrannye proizvedeniya. Moscow: Progress, pp. 602-643.

MASON, I. 2004. Conduits, Mediators, Spokespersons: Investigating Translator/Interpreter Behaviour. In Translation Research \& Interpreting Research: Traditions, Gaps and Synorgies / Edited by Christina Schäffner. Multilingual Matters, pp. 88-97.

XLinguae Journal, Volume 9 Issue 2, April 2016, ISSN 1337-8384 
PODDUBNOVA, A.A. 2013. Translational activity: communicative tasks. In Актуальні проблеми металінгвістики: збірник наукових праць / МОН Украіни. Черкаський нацю ун-т ім. Б. Хмельницъкого; Інститут мовознавства ім. О.О. Потебні НАН Украіти; відпю ред. Л.В. Корновенко. - Черкаси: Видав. Чабаненко Ю.А., pp. 85-87.

Excursions in English for foreign tourists in Volgograd former Stalingrad. Retrieved from: <http://www.youtube.com/watch?v=KCWhnZHSirE (accessed at 03.04.2015) >. Excursions in English in Volgograd. "Battle of Stalingrad" panoramic museum // Tours and excursions in Volgograd. Tourist services \& Russian visa support. volgograd.sputnik@gmail.com. Retrieved from: $<$ http://www.youtube.com/watch?t=4\&v=cv_6Q6fd0ZI $>$ (accessed at 07.04.2015). Gavin Webb, Tour Guide of London. Retrieved from: $<$ http://www.tripadvisor.co.uk/Attraction_Review-g186338-d1818020-Reviews-

Gavin_Webb_Tour_Guide_of_London-London_England.html $>$ (accessed at $05.09 . \overline{2} 015)$.

Moscow_Free_Tour. Retrieved from: <http://www.tripadvisor.ru/Attraction_Reviewg298484-d2196855-Reviews-Moscow_Free_Tour-Moscow_Central_Russia.httml> (accessed at 05.04.2015).

Sightseeing in Volgograd. Mamyev Hill. Retrieved from: $<\mathrm{http}: / /$ www.youtube.com/watch? $\mathrm{v}=$ _k2s1DsPDWs $>$ (accessed at 18.04.2015).

Tours in English in Volgograd // Tours and excursions in Volgograd. Tourist services \& Russian visa support. volgograd.sputnik@gmail.com. Retrieved from: $<$ http://www.youtube.com/watch?v=2TRfVwKNfyo $>$ (accessed at 03.04.2015).

Visiting war memorial at Mamayev Hill with English speaking guide. Retrieved from: $<$ http://www.youtube.com/watch?v=-H-2GTqob9Q $>$ (accessed at 10.04.2015).

Words: 5952

Characters: 41414 (23 standard pages)

Anna A. Gureeva, DrSc.

Ass. Prof, Elina Yu. Novikova, DrSc.

Prof. Vera A. Mityagina, DrSc.

Department of Translation Theory and Practice

Institute of Philology and Intercultural Communication

Volgograd State University

Prospect Universitetsky, 100

400062, Volgograd

Russia

tipp@volsu.ru 